\title{
MORSWMAN SHIP.
}



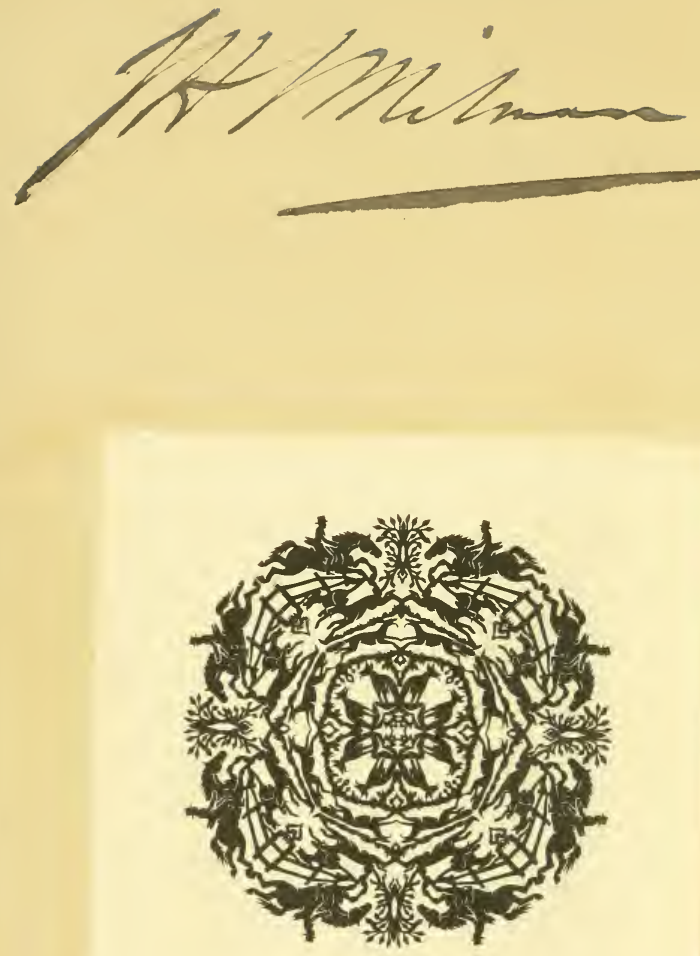

JOHN A.SEAVERNS 
TUFTS UNIVERSITY LIBRARIES

$\begin{array}{llll}90090 & 013 & 401 & 001\end{array}$

Webster Family Library of Veterinary Medicine Cummings School of Veterinary Medicine at Tufts University

200 Westboro Road

North Grafton, MA 01536 

THE

\section{LADY AND HER HORSE,}

\section{BEING HINTS SELECTED}

FROM VARIOUS SOURCES

\section{AND COMPILED INTO A SYSTEM}

OF

EQUITATION.

BY

MAJOR T, A. JENKINS.

\section{MADRAS :}

PRINTED AND PUBLISHED BY PHAROAH AND CO. ATHENAUM FHESS, MOUNT ROAD.

1857. 


\section{CONTENTS.}

Page.

Introductory Address.................. 1

Preparatory Remarks.................. 2

Directions for Mounting................. 5

The Seat and Balance.................. 7

Holding the Reins................... 10

Aids and Indications.................. 11

Guiding. ...................... 16

Animations......................... 22

Soothing..................... 24

Corrections....................... 25

Vices.......................... 26

Paces of the Horse................... 33

Leaping......................... 39

Road Riding....................... 41

Dismounting. ..................... 46

Concluding Remarks................ 48 



\section{EQUITATION.}

\section{INTRODUCTORY ADDRESS.}

"W What delight

"To back the flying Steed, that challenges

"The wind for speed! Seems native more of Air,

"Than Earth! Whose burden only lends him fire !

" Whose soul is in his task, turns labour into sport

"And makes your pastime his !"

\section{'Love Chase.'}

"THE chief point in Horsemanship", Colonel Greenwoon observes in his "Hints on Horsemanship" "is to get your horse to be of your party; and not only to obey, but to obey willingly,"- "Good riding as a whole is indeed no trifle, and is worth acquiring by those whose pleasure or business it is to ride, because it is soon, and easily acquired, and when acquired it becomes habitual, and is as easy, nay much more so; and infinitely more safe, than bad riding. Good rid. ing is an affair of skill, but bad riding is an affair of courage." Yet, in no other art, are there so many self-thought Amateurs. Nany ladies 
have a decided objection to going through the ordeal of a riding school; others have no opportunity of obtaining instructions, and the generality consider, that they are in possession of all that can be acquired upon the subject, when they have discovered a mode of retaining the seat, and guiding the horse; but to those who wish to sit a horse through all his paces, firmly, yet gracefully, to have the animal entirely under command, and as if imbued with one intelligence, to unite boldness, with modesty, and employ energy, without losing delicacy, these hints are addressed:

\section{PREPARATURY REMARKS.}

A lady's riding dress, should be neat, and compact, at the same time she should carefully aroid the slightest approach to a mannish appearance; she may study the becoming, provided there be nothing in her whole toilette likely to become dis. arranged or loosened by wind, or violent exercise. The hair should be so arranged that it cannot be blown about the eyes, and the hat should be perfectly secured on the head. So much for outward appearance, in other respects comfort alone should be studied.

The whip, should be light, and stiff. When too pliable, a lady frequently touches her horse 
with it unintentionally, thereby teasing and exciting him, and moreover such a whip is useless as an "aid."

The lady's bridle, should be, what is called a double bitted bridle, consisting of a bit with a curb-chain; and a snaffle, two separate head-stalls, united by one brow-band, each, with a separate rein.

The curb-bit is a very powerful implement, the best for all purposes is a light one ; in choosing a bit for a horse, the distance between the cheeks, should accord with the width of the horse's mouth ; they should be of an average length, and the mouthpiece should be only sufficiently arched, to admit of the horse's tongue passing freely underneath it. The bit should be placed in the horse's mouth, so that the mouth-piece be one inch above the lower tusk, the curb chain should be laid flat, and smooth under the jaw, and so loose, as to allow a finger to pass freely inside of it.

The snaffle acts as an auxiliary to the curb-bit, and is placed above it in the horse's mouth, it should bear slightly upon the corners of the mouth, but not so as to wrinkle the cheelss.

For a person who has not a light hand, the curb. bit may, with advantage, be placed a little higher in the horse's mouth; and when the mouth may be wanting in delicacy, it may be lowered a little, but 
it should never touch the tusk, or it will fret the horse.

The reins should be soft, flexible, and of a good quality, the rein which is attached to the curb-bit is usually fastened in the centre by a sewing, while that attached to the snaffle may be known, by its having a small buckle in the centre.

Throat-strap should not be buckled too tightly, but only sufficiently so, to prevent the headstalls of the bridle, from getting out of place.

Martingales, though frequently used, are very seldom necessary if the horse has been educated, and taught to carry his head properly, and to be obclient to the bit; but if a horse carries his head high, or be unsteady and fretful, then a light running martingale will be found of service; it must however be attached to the snaffle reins, and never to the curb-bit reins.

The saddle should be roomy, but not too large, it should in short, be made to fit the person. The third crutch is indispensable, as it renders the seat so much more, secure, and if properly fitted, it never incommodes the rider. The saddle should be placed on the horse's back, so as not in the least to interfere with the action of the horse's shoulder, and care must be taken that the pad, or stuffing, only rests on the horse's ribs, leaving in the centre a thorough ehannel, over the spine. 
The lady's horse should be good tempered, free and willing, for a sluggish horse is the most unpleasant of any to a lady; but he must not be restless, nor impatient in company: he should be steady, and safe on the roads, smooth in all his paces; and with these natural qualifications which are essential, he must be properly broken, and taught to go collectedly in all his paces; and particularly to lead off in a canter with the right leg; to arch his neck on the reins being felt, to be obedient, and light in hand; it is further desirable that the horse should possess elegance of figure, power, and action, with speed in all his paces. However, much will depend upon the person, for whom he is intended, as a timid rider would be alarmed by the sprightliness of a free going horse, which might perfectly suit a lady with a light hand, and a steady seat. A young horse is natu. rally unsteady, the beau ideal of a lady's horse, is an officer's charger, about ten years old, as he still possesses life and spirit, without the freshness of a colt.

DIRECTIONS FOR MOUNTING.

Ture lady holding the falling folds of her habit in both hands, walks up to the horse's head, or 
side; but never behind him, lest he should kick at her.

There should be two persons in attendance, the groom should stand before the horse's head, with a hand on each side of the bridle close to his mouth, to keep him steady; the gentleman takes the reins in his left hand, separating them with his forefingers, the lady receives them in her right hand, in like manner, and lets them glide gently and evenly through her fingers, until her hand reaches the near crutch, which she takes hold of ; and having passed the whip over the saddle, she holds it also in her right hand. Standing close to the near side of the saddle, and facing the gentleman who has taken a lock of the mane in his left hand, the lady places her left foot, which he stoops to receive, full in his right hand, lets the habit fall from her left hand, which she places upon his right shoulder, leaning thereon, and assisted by her hold on the crutch, she springs up from her right instep, as uprightly as possible, having been careful not to place her left foot too far forward, but keeping it directly under her, she straightens her left knee and assumes an upright position; the gentleman, when he feels her spring, accelerates the movement, by simultaneously lifting his hand high enough, to place the lady on the saddle, she steadying herself, by the hold she has with her right 
hand, seats herself, and places her right leg between the two outward pommels, the gentleman places her foot in the stirrup, and she takes the reins in her left hand. To adjust the habit, the lady raises herself by placing her right hand on the off pommel and standing in her stirrup, the gentleman shakes the back part of the skirt into its place, she re-seats herself, and raising her right knee to free the habit, the gentleman assists to adjust the front part of the skirt by gently drawing it forward.

\section{THE SEAT AND BALANCE,}

A LADY seldom appears to greater adrantage than when mounted on a fine horse, that is, if her deportment be graceful; and her position corres. ponds with his paces and attitudes; but the reverse is the case, if, instead of acting with, and influencing the movements of, the horse, she appears to be tossed to and fro, and overcome by them. She should rise, and descend, advance, and stop with, and not after the animal. From this harmony of motion results ease, elegance, and a good effect. The lady should sit in such a position, that the weight of her body may rest on the centre of the saddle, and so far back, as just to admit of her right leg passing easily round the 
crutch, for if the knee be too far forward, the seat will be very insecure; the right foot should be flat to the saddle, the toe turned downwards, that it may not be seen through the habit, when a firmer seat is required, the heel should be depressed, as doing so, will tend to brace the muscles of the leg, and give a firmer hold on the crutch.

The left $\log$ and knee must be in close contact with the saddle, from the knee the leg should fall in a natural position, the foot should be parallel to the horse's side, and close to it, the heel slightly depressed. The stirrup leather should be adjusted accordingly, as it is only of use, to support the foot in its proper position, too long a stirrup throws the rider on one side, and raises the right hip, too short a stirrup again, forces the knee outwards, and throws the seat too much to the right, giving to the rider a distorted appearance. $\mathbf{A}$ small strap fastened to the surcingle about two inches above the stirrup, passing round the stirrup leather, with a play of about three inches, adds greatly to the security of the seat, as it prevents the leg from flying out from the saddle.

The arms should hang straight down from the shoulder, nearly close to the sides, but not stifly, the elbows bent, and the hands level with the elbows, the right arm and hand, when not occupied with the reins, may be allowed to hang straight 
from the shoulder. The whip should be held with the lash downwards, between the two fingers and thumb. The whip may also be carried in the man. ner adopted by gentlemen; but care should be taken that its point does not tickle, or irritate the horse.

The proper position of the bridle hand, is immediately opposite to the centre of the waist, and about three or four inches from it, the wrist should be slightly rounded, the back of the hand to the front, the knuckles opposite to the horse's ears, the thumb uppermost, and pressed over the third joint of the finger. The hand should not be allowed to move across the body, all the movements being made by the wrist. The arm from the shoulder to the waist, must be one continued spring, impulsive to the motion of the horse's head, moving backwards and forwards as he moves, for if it be not so, the horse's mouth will be spoiled by the dead pull upon it.

The body must always be in a situation, as well to preserve the balance, as to maintain the seat. The shoulders should be thrown back, so as to open the chest as much as possible. The rider should look in the direction, and lean to the side the horse is turning to, which is in fact the necessary $b a$ lance. 
There are various ways of holding the reins, depending upon fancy, and circumstances; such as the fineness of a horse's mouth, and the delicacy of the rider's hand.

Holding a single rein.-The rein is taken in the centre where the joining is, between the forefinger and thumb of the right hand, and drawn to. wards the body, the left hand is placed over the reins, and the little finger is inserted between them; the hand is them closed, and the reins are drawn through the fingers, by the right hand, until a proper feeling is obtained upon the horse's mouth; the loop end of the rein is allowed to drop over the fore-finger, and the thumb is placed upon the rein, to prevent its slipping.

Holding a double rein. - The curb rein being held as directed, the loop of the snaffle rein is placed over the curb rein in the palm of the left hand, or, to have a double bearing upon the horse's mouth, the rein may be drawn, till the required tension is obtained, the left rein lying over the curb rein in the palm of the hand, the right snaffle rein, passing between the second and third fingers. In dividing the reins with the little finger, the right rein, which passes over that finger, is always a lit- 
tle longer than the other, and requires to be shortened, if this be not attended to, the horse will be ridden chiefly upon the left rein, his head will be bent to the left, and he will not be looking the way he is going.

Holding the Curb and snaffe reins separated.The curb being held as directed in the first described method, the snaffle rein is taken in the same manner, in the right hand, below the left ; the principal bearing is brought upon this rein, which keeps the horse's head steady, while with the left hand the horse's mouth is kept alive, by a play on the bit, giving and taking, but, at the same time retaining a light bearing upon the horse's mouth. This is an excellent method for holding the reins with a fiery, high actioned horse, not up to hand.

Adjusting the reins. - The rider should take hold of the loop end of the rein, and draw it through her hand until the proper bearing and tension has been obtained.

\section{AIDS AND INDICATIONS.}

Alc those motions of the body, the hand, the leg, and the whip, which either indicate the rider's wishes, or in some degree assist the horse to per-. form them, are, in the art of riding denominated ' aids ;' in their execution, a perfect combination, 
and the greatest uniformity, exactness, and delicacy are required.

The indications of the hand are of two sorts, guiding and retaining, those of the leg and whip, are also of two sorts, guiding and urging. The aids serve to put the horse in movement, to direct, and to stop him ; they should not only decide the pace which the horse is to take, but also signify to him, the rate at which each pace is to be executed, and also determine his carriage during the performance of it. The power of these aids, and the degree of severity to be used, must be governed by circumstances, and the sensibility of the horse.

The hand, being placed holding the reins, as previously described, and the reins being drawn to that determined length, that the bracing of the muscles of the hand would rein the horse back, and the easing of them permit him to advance freely; if the hand be held steady, as the horse advances in a trot, the fingers will feel by the tightening and loosening of the reins, a slight sensation or tug, occasioned by the measure or cadence of every step, this sensation or tug, which is reciprocally felt in the horse's mouth, by means of the correspondence between the hand and the mouth, is called the appui ; and while this appui is preserved, the horse is in perfect obedience to the 
rider, the hand directing him with the greatest ease, so that the horse seems to work by the will of the rider, rather than by the compulsion of the hand.

When a horse is ridden on a snaffle, he only feels the direct pull more or less of the rider's hand, with a curb-bit in his mouth the effect is different, and more powerful, on account of the lever which tightens the curb-chain on the horse's jaw. A curb in a rough and uneven hand, becomes an instrument of extreme torture; the hand should always be firm, but delicate, the horse's mouth should never be surprised, by any sudden transition of the bearing from tight to slack, or from slack to tight, every thing in horsemanship should be effected by degrees.

The rider should never rest her hand upon the pommel, as by doing so, she at once destroys the sympathy which ought to exist between the hand and the horse's mouth.

Fineness of mouth, means a mouth that is perfectly trained, and responds to the determined action of a sensitive hand. The acquirement of the bearing upon the horse's mouth, the turning the horse upon the proper rein, the power of collecting the horse, and retaining him on his proper balance, smoothness of indications, in the shortening of the reins, and the working together of the hand, leg, 
and whip, are the unseen, and unappreciated foundation, upon which good riding stands; these, and not strength, nor violence commands the animal, with these, the horse will rely on the hand, comply to it, and without force on the rider's part, he will bend to the hand in every articulation. Without these, however unintentional on the rider's part, she will be perpetually subjecting him to the severest torture, to defend himself against which, he will resist the hand, poke his nose, stiffen his neck, and every other part of his body; for the horse can endure no greater torture, than that resulting from an uneven hand.

The Leg and Whip.-The leg should hang straight from the knee, easy and steady, and be near to the horse's sides; the pressure being increased as occasion required, but the size and substance of the flap of the saddle, in numerous cases, renders the pressure of the leg nugatory, therefore, as the whip is the chief additional aid a lady has to depend upon, its exact management ought to be reduced to a perfect science. Every movement and louch of the whip must be made for purpose and effect; it can be used on both sides of the horse, as the case may require; the lady will have no difficulty in using it, on the right, or off side of the horse: but to use the whip on the near side requires caution and address. 
To strike the near forehand; the lady should raise the whip gently to an upright position, holding it with a firm grasp, she should then let the whip suddenly descend along the shoulder, and instantly remove it : she should be careful not to strike the horse on any part of the head except in cases of vice. To strike the near hind quarters, the lady must pass her right hand gently behind her waist, as far as the arm will reach, without distorting the body; and holding the whip between the two first fingers and thumb, strike the horse. This position is most excellent practice, by compelling the pupil to draw in her waist to its proper place: and until a lady can perform it easily, without disturbing the position and action of her bridle hand, she will fail in attaining a graceful and elegant carriage. The whip on the one side, pressed to the horse's side, corresponds with the leg on the other, but except in moving straight-forward, they should not be applied op. posite to each other; that the pressure of one, may not counteract the effect of the other; thus the one intended to communicate a forward impulse, should be applied further forward, to keep the horse up to hand, than that, which communicates an impulse to the horse to step side ways, which should be applied behind the girth.

The rider must always bear in mind, that every 
movement of the bridle, the leg, and of the whip, is felt, and responded to, by the sensitiveness of the horse; when she errs, the horse goes wrong, it is therefore indispensable that they should act in conjunction.

\section{GUIDING.}

The horse, previous to moving forward, should be made to collect himself, to arch his neck, and to stand evenly upon both his hind legs, for thereupon depends the balance of the horse's body, his lightness in hand, and proper carriage.

To adrance.-The lady should call the attention of the horse, by an increased bearing upon the reins, and at the same time should animate him, by closing the leg, and using the whip gently on the right flank; having communicated a sufficient impulse to the horse, to carry him forward, she should at the same moment, by turning up the back of her hand, ease the pressure upon the reins, and prevent him to more forward: but she should not slacken the reins, because by doing so, the horse's head and neck may relapse into a position, which the hand cannot control.

To turn the horse, Colonel Grennwoon in his book of "Hints on Horsemanship" obserres, "When you wish to turn to the right, pull the right rein stronger than the left; this is common 
sense-the common error is, when you wish to turn to the right, to pass the hand to the right, by which the right rein is slackened, and the left rein tightened, across the horse's neck; and the horse is required to turn to the right, when the left rein is pulled."

To turn to the right.-The hand, holding the reins the proper length, and having a correct appui or feeling of the horse's mouth, must not be moved from its position, in a line with the crest; but the tightening of the rein, must be effected, by turning the wrist; the little finger, with the first joint pressing against the rein, is raised, and turned towards the right shoulder; thus giving a double feeling, or pressure upon the right rein, and turning the horse's head in the desired direction, the pressure of the left rein against the neck, which follows, induces the horse to turn to the right. Or the right hand may be placed upon the right rein, to tighten it. 'The pressure with the left leg, should at the same time be increased, to prevent the horse from throwing his hind quarters too much outwards, or to the left. The rider's body should incline inwards, and face the direction turning to. If the whip be used, it should be applied upon the left shoulder, with a continued pressure, till the turn has been completed.

To turn to the left.- The lady should increase 
the bearing upon the left rein, by turning the back of her hand downwards, so as to bring the little finger towards the left shoulder; at the same time, she should apply the whip to the horse's right flank, to make him collect himself, and to prevent him, from throwing his hind-quarters too much to the right; when the horse has completed - the turn, the bearing and pressure should be equalized, to induce the horse to move straight forward.

The horse, when at a stop, may be made to turn quite round by making him move his hindquarters only.

To circle the liorse to the right, on his fore.-hand. -The lady should apply her leg, to the horse's side, as far back as she can; to induce him to step to the right, with his hind legs; at the same time, she must increase the bearing upon the left rein; if the horse does not readily obey the pressure of the foot, she may pass her hand behind her waist, and touch the horse with the whip gently on his left flank.

To circle the horse to the left, on the forehand.The lady should apply the whip gently to the horse's right flank, to induce him to step to the left, she should have a double bearing upon the right rein, and she should at the same time press her foot against the horse's side, as far forward as she can, to oppose the movement of the fore-legs. 
The horse can be made to turn on his hind legs, by the movement only of his fore-hand. The lady to turn the hor'se to the right, must apply her leg as far back as possible, to keep the horse's haunches steady; at the same time, she should with the bit, bend the horse's head a little to the right, to induce him to step with his fore-feet to the right. If necessary, the whip may be used, by gentle touches upon the left shoulder.

To turn on the haunches to the left.-The lady must press her whip on the horse's right flank, and her leg, against his side as far forward as pos. sible, at the same time, she should communicate an impulse to the horse, to step to the left, to turn the horse quite round when in movement; the lady should first bring her horse to a momentary stop, and then proceed to turn him.

To stop.-The lady must close her leg smartly to the horse's side, to make him bring his baunches under him; at the same instant she must increase the bearing upon the reins, gradually yet firmly, by turning the back of her bridle hand downwards, and drawing it back, and upwards; the body should also be thrown backwards, to give weight to the pull : as soon as the horse has obeyed the check and remains still, the lady should ease the bearing upon the reins. If the lady does not give an impulse to the horse, by the pressure of her leg to his 
side, to bring his haunches under him, but merely pulls the bridle, the horse might be stopped by strength of arm, but it would be entirely on his fore-hand; and she would be thrown up and down in her saddle, in a very helpless way.

The stop should not be made too suddenly.

Reining back.-The great use of reining back, is to render the horse obedient, and tractable. The lady should first make her horse collect himself, when well balanced, she should communicate an impulse to the horse, by the pressure of her leg and whip to his sides, to induce him to raise one of his hind feet, at the moment of his doing so, she should double the feeling upon both reins, by drawing her hand back, and turning her little finger up towards her chest; the horse, to recover his ba. lance, will step back. The movement of the hand must be repeated, at each step of the horse; should the horse bring his haunches too much under him, the bearing upon the reins must be eased, and the pressure of the leg and whip, increased, to give him a forward impulse.

The horse must not be allowed to hurry, or run back out of hand, nor to diverge from the straight line; he should be guided, by an increased pressure of either rein, as may be necessary, and by an additional pressure with the leg, or whip, to keep his hind-quarters in the desired direction. 
Reining in.-The object desired is, to make the horse assume a more correct balance. The lady should shorten her reins a little, by drawing them through her left hand, thus keeping the bit-hand low and steady, with an extra bearing upon the reins; she should with her right hand, play with the snaflle rein, and at the same time, communicate to the horse a forward impulse; the horse feeling the bit to be an insurmountable obstacle, will, in place of throwing his weight forward, bring his haunches under him. Should the urging indication be applied too abruptly, the horse may throw so much weight forward, as to pull the reins out of the rider's hands; if used judiciously, and controlled by the hand, the horse will collect himself, arch his neck, champ the bit, and be ready for any movement.

This practice gives the horse confidence, for most young horses are afraid of the bit; and if frightened by too sudden a jerk upon the rein ${ }^{\text {s }}$ will never after, go kindly up to hand. The lady having learnt the indications necessary, to induce the horse to move either, his fore-hand round his haunches, or his croup round his fore-hand; may next proceed to apply them, so as to induce the horse to move diagonally, or sideways.

Shoulder in.-In this movement the horse's body is bent more or less. The pupil should 
separate her reins, and take one in each hand, holding them rather short; if the horse is to move to the left, her right hand must be drawn back to her hip, to bend the horse's head to the right, her left hand should be advanced to guide the horse, she must apply her whip by light touches to the horse's right side, in line with the girths, to induce him to step diagonally.

Passaging.-Signifies moving side ways.--If the retaining and urging indications be given with equal force, but the right rein be felt the stronger, the horse will incline to the right; to induce him to move his hind quarters also in that direction, the urging indication upon the left flank must be increased, by the rider applying her leg to the horse's side, as far back as she can, if necessary, she may pass her whip behind her waist, and touch the horse with it, on his left flank.

In passaging to the left, the whip should be used by gentle touches, on the horse's right shoulder, or flank as may be necessary.

The rider should lean to the side, the horse is moving to.

ANIMATIONS.

Animations are intended to produce greater speed, or to render the horse more lively, and on the alert, without increasing his pace; some horses 
scarcely ever require animations, while others are so dull, and deficient in mettle, as to call them frequently into use. The slightest movement of the body, the hand, or the leg, is enough to rouse the well bred, and thoroughly trained animal ; but it is necessary with sluggish horses, that the animations, to be so spirited and united, as almost to become corrections : in fact, what is mere animation to the one horse, would be a positive correction to another.

Animations should be used in all cases, when the horse, contrary to the rider's inclination, either decreases his speed, droops his head, bears heavily and languidly upon the bit, or begins to be lazy and slovenly in the performance of his pace. A good rider foresees the necessity for an animation, before the horse actually abates his speed, or loses the ensemble of his action, and the grace and spirit of his deportment.

It is much easier to maintain, than to restore a horse's animation ; therefore, the whip, the hand, the leg, or the voice, should do its office a few moments before, rather than at a time, when doing so has become indispensable. A slight motion of the fingers of the bridle hand, serves as an excellent animation; it reminds the horse of his duty, awakens the sensibility of his mouth, and preserves a proper correspondence between that, and the 
hand. When it is necessary to recur to animation frequently, they ought to be varied ; even the whip, if it be often used, unless with different degrees of force, will lose its effect.

\section{SOOTHINGS.}

WE should endeavor, as Xenophon observes, "to make ourself to our horse, the organ of pleasure, and that he should associate with our presence, the idea of the absence of pain." Horses are by degrees made obedient, through the hope of recompense, as well as the fear of punishment; to use these two incentives with judgment, is a very difficult matter, requiring much thought, much practice and good temper; mere force, and want of skill, and coolness, tend to confirm vice and restiveness. The voice, the leg and the whole body, may be employed to soothe and encourage. High mettled or fretful horses, it is often neces. sary to soothe, and timid ones to encourage. A spirited animal is frequently impatient when first mounted, or if a horse or carriage pass him at a quick rate; in either case, the rider should endea. vor to soothe her horse, by speaking to him in a calm gentle tone; she should keep her whip as motionless as possible, taking even more care than usual, that its lash do not touch his flank, her 
seat should be easy, her leg still, and her bridle hand steady. The perfection of soothing consists in the rider sitting so still, and easy, as not to add in the least, to the horse's animation, at the same time being on her guard, so as to be able to meet any contingency that may occur.

\section{CORRECTIONS.}

THE best horse sometimes requires correction, but the sooner a lady gets rid of a horse that she is compelled to flog, the better; the effect is most unpleasant, though the éclát may be great, and such a sight would destroy every previously formed idea of her grace and gentleness: moderate corrections are however some times necessary, and the lady should make no scruple of having recourse to them when absolutely necessary, but not otherwise. The best way to correct a horse is to dishearten him, and make him do what he would fain avoid, not so much by force and obstinate re. solution, in contesting with him openly, and directly, when he is perfectly prepared to resist; as by a cool opposition, and indirect means. There are different methods of attaining the same end, and those which are the least obvious to the animal should be adopted; a lady cannot rival him in physical strength, but she may conquer him by 
ingenuity, or subdue him by a calm determined assumption of superior power : severe flogging seldom produces good effect, and all quarrels between a horse and his rider should be aroided; on the other hand, too much indulgence may induce him to think that she is afraid of him; should he do so, she will find that he will exercise every means to convince her, that he considers himself her master, instead of acknowledging by implict obedience, that she is his.

When it is necessary to use the whip as a correction, it should be applied, by giving the horse two or three smart cuts in a line with the girths, or on the shoulder. The lady should not fret her horse, by continually tapping him with the whip.

VICES.

THE w ord vice, is used to signify those actions which arise from a perverse, or mischievous disposition-those, in which the horse opposes his own will, to that of his rider, or those in which he purposely attempts to injure other horses, or the persons about him. A lady certainly should not ride any horse, that is addicted to shying, stumbling, rearing, or any other kind of vice; but she ought nevertheless, to be prepared against their occurrence; for, however careful, and judicious 
those persons, by whom her horse is selected, may be, and however long a trial she may have had of his temper, and merits, she cannot be sure, even with the best tempered horse, that she may not have to exercise her skill, to save herself from danger ; she should therefore, be prepared against frailty, or accident.

When a horse resists, or suddenly becomes uneasy in his gait, instead of punishing the animal; the bridle, saddle, girths, \&c., should be examined, to ascertain the cause, and remedy it. For want of this necessary precaution, the poor animal is often used ill, without reason, and being forced into despair, is in a manner obliged to act accord. ingly, be his temper and inclination ever so good.

Weakness frequently drives horses into being vicious, when any thing beyond their strength is required of them : great care should therefore be taken, to ascertain from what cause the opposition arises.

Resistance in horses, is often a mark of strength and vigour, and proceeds from high spirits, but punishment would turn it into vice; a timorous rider, or a passionate person, would alike spoil the horse; the former, by suffering him to have his own will, establishes bad habits, and creates new ones; for horses find out many ways, and means of opposing what is demanded to them; many will 
imperceptibly gain a little every day on their riders; the lady must however always treat the horse kindly, at the same time show him that she does not fear him. The other, from want of reason, and temper, enrages the horse, and causes him to become vicious. Horses of a bad disposition or temper, are exceedingly subtle, and watch their opportunity; they first, as it were, feel for their rider's firmness of seat, and her resolution, and are sure to defend themselves upon that point, on which they expect she will attack them; now, the object of the lady in this contest must be, to frustrate the horse's intentions, and protect herself from injury in the struggle.

Some horses have a vicious habit of turning round suddenly; instead of endeavouring to prevent him, in which the lady would in all probabilty be foiled, were she to try to do so by force; the better plan is, to turn the horse smartly round to the side to which he is turning, until his head has made a complete circle, and he finds to his astonishment, that he is precisely in the place from which he started. Should he, on the lady attempt. ing to urge him forward, repeat the trick; she should pull him round on the same side three or four times, and assist the hand in doing so, by a smart aid of the whip, or the leg; while this is doing, she must take care to preserve her balance, 
by an inclination of the body, towards the centre of the circle which is described by the horse's head in his revolution. The same plan may be pursued, when the horse endeavors to turn a corner contrary to ths wish of his rider; and if he be successfully baffled three or four times, it is most probable that he will not renew his attempts.

When a horse refuses to advance, and probably whipping would increase his obstinacy, or make him rear, or bolt away in an opposite direction, it is advisable, on the same principle, to make him walk backwards, until he erinces a willingness to advance : should the rider not mind her horse giv. ing a kick or two, a couple of smart cuts over the croup, will generally prove successful.

Should a horse back into difficulties; he must be turned with his head towards the danger, and then backed off, until there be sufficient room to handle him.

Restive horses, and even docile animals when put out of temper, sometimes rear up against a wall or a carriage; an inexperienced rider, in such a situation, would strive to pull his head from the wall, which would bring her knee incontact with it, consequently, all further chastisement thereupon ceases; for were the rider to make her horse plunge, her legs would be crushed against the wall, the 
horse discovering the rider's weakness, and that punishment had ceased; would turn it to her disadvantage, and on future occasions fly to the wall for shelter. Instead of from the wall. The horse's head should be pulled towarls it, so as to place his eye, in place of his rider's knee, against it. She should use her leg, and whip, to force the croup out, when the horse can be easily backed off, and he will never go near a wall again.

Some horses will stand stock still, if ladies have the patience to sit on their backs, and keep them in the same spot for a time, it is the most proper punishment for such an offence, and will surely cure that mode of defence.

When a horse begins to lick, the rider must bear forcibly upon his mouth, and keep his head up, at the same time, she should press her leg to the horse's side, keeping her body well back, to save herself from being thrown forwards. She should use as little coercion as possible, and be careful to preserve her own temper, and her seat; should the horse, in spite of her exertions, get his head down; she must endeavour to give him a smart blow with her whip on his head, which will induce him to throw it up, and thereby stop his kicking; should an opportunity occur, she should also try to give the horse, two or three smart turns; this may also be done with effect, as a 
preventative, should she detect any incipient attempts in the animal to kick.

Rearing is a bad vice, and in weak horses especially, a dangerous one. When the horse rears, the rider must cease to bear upon the mouth, she should lean her body well forward, towards his neck, and with her right hand take hold of the mane, to save herself from falling off, or pulling the horse backwards upon her; as the horse comes to the ground with his fore feet, not before, she should give him a few smart cuts with the whip on his croup, to force him forward, and endeavor to pull him round two or three times, and thus divert him from his object; the latter course may also be adopted to prevent rearing, if the rider can foresee the horse's intention.

If a lady have the misfortune to be mounted on a runaway horse, she may avoid evil consequences, if she can but contrive to retain her self-possession. She must endeavor also to retain her seat at all hazards, sitting well back and perfectly quiet, for the least symptom of alarm on her part, will increase the terror, or determination of the horse. She should not attempt to throw herself off the horse, except in cases when the horse may be taking her into imminent danger; she should separate her reins, holding the curb in her left hand, and the snaffle in her right, and pull at each 
alternately; which renders the mouth more sensitive, than a dead heavy pull upon any one bit, and the horse consequently more obedient to the hand. Should an open space present itself, turning a horse in a circle, will frequently bring him up in a few seconds.

Plunging, is very common amongst restivehorses. If the horse continue to do so in one place, or backing; he must be urged forward; but if the horse does it flying forward, he should be kept back, and ridden slowly for some time.

Starling, often proceeds from a defect in sight, which therefore should be carefully looked to. When a horse starts or shies, no notice should be taken of the movement, further, than to meet him, with the proper bearings and pressures, to compel him to move in the true direction; should he however, be alarmed at an object, and instead of going up to, or passing it, turn round; he should he soothed, and brought up gently to it, carressed at every step, ho advances. To attempt to force the horse up to the object he dreads, would not only be ridiculous and dangerous, but the punishment would add to the alarm, and the horse would take an early opportunity to shy afresh, at the first strange object that presented itself, and very probably he would add another start, in anticipation of the chastisement that might be 
in store for him. Thus, what was originally a failing from defect of vision, or ebullition of spirit from over feeding, or want of proper exercise, becomes a vice rooted, and confirmed, and of a dangerous character. When passing an object that the horse may be alarmed at, his head should be turned away from it, rather than towards it, a good rider thus prevents her horse from shying, while the young and bad rider, by the reverse treatment, of pulling a horse's head towards the object, and whipping him up to it, makes her horse shy. The horse should never be allowed to evade passing the object, but he should be got past in the manner, that occasions the least alarm to, or contention with him.

When the horse starts, the rider should instantly direct her eyes to the horse's ears, when her body will naturally take the same direction that the horse shies to, but if her eyes be directed to what the horse shies from, she may loose her balance, and fall.

\section{PACES OF THE HORSE.}

THe walk is the least raised, the slowest, and the most gentle of all the paces; but it should be an animated quick step, and to be pleasant to the rider, it must be true; that is, it should be con- 
ducted by a harmonious elevation and setting down of the feet, each foot being dropped flat on the ground, and'not, as is too often the case, the toe being placed first, and then the heel. One lady by a good seat and hand, will cause her horse to carry his head, with his neck arched, and to elevate and extend his limbs, the one in unison with the other; another, by her bad hand, and seat, will bring the horse she rides, to step short, and irregular, and so mix his trot, with his walk, as to do little more than shuffle over the ground.

Previous to urging the horse into a walk, the lady should ascertain that he is well in hand, and on his proper balance; then, by turning her hand, with the little finger towards her breast, she must increase the bearing upon the horse's mouth, to draw his attention, and at the same instant, she must communicate to him, by closing the leg, and using the whip gently upon the right side, a sufficient impulse to carry him forward, easing, as he advances, the bearing upon the mouth, by the hand resuming its proper position, but she must not slacken the reins.

In the walk, the reins should be held so that the rider have a delicate, but distinct feeling of the horse's mouth, to cause the horse to carry his head in a proper position, and to keep time in the beats of his action, but not held so tightly, as to 
impede the measurement of his steps, or to make him, on being slightly animated, break from a walk into a trot.

The rider's body should be erect but pliable, neither obeying too much the action of the horse, nor yet resisting it.

If the horse do not exert himself sufficiently, or hang on the bit, he should be animated, by a play on the snaffle bridle; should he break into a trot, he must be checked, but the bearing upon the reins, must neither be so firm nor continued, as to make him stop.

The trot, is a more animated pace. To make the horse advance from the walk into a trot, the horse must, with the leg and whip, be urged into greater animation, at the same time retained, by an increased bearing upon the reins. The lady must be careful, to retain the lightness in hand, without counteracting the impulse necessary to the movement, when the animal will proceed with that safety, which is natural to a horse balanced and light in hand.

When the horse trots, the lady must preserve her balance, steadiness and pliancy, as in the walk; the rise in the trot, is to be acquired by practice; when the horse in his action raises the rider from her seat, she should advance her body, and rest a considerable portion of her weight, upon her right 
knee; by means of which and the bearing of her left foot upon the stirrup, she may return to her former position, without being jerked; but she must carefully time her movements to the horse's action, and the closer she maintains her seat, consistently with her own comfort the better.

The Canter, and Gallop, are paces of still higher animation; the canter is a repetition of bounds, during which the forehand raises first, and higher than the hind quarters; it is the most elegant and agreeable of all the paces, when properly performed by horse and rider; its perfection consists in its union and animation, rather than its speed.

A horse may canter false, disunited with the fore, or disunited with the hind legs, for instance, if a horse is cantering in a circle to the right, leads with his near fore leg, followed by the near hind leg, he is cantering false. If leading with the near fore leg, the off hind, remains further back than the near one, he is said to be disunited; if leading with the proper fore leg, the off hind remains further back than the left, the pace must be rectified. The lady should learn to ascertain by the motion of the horse, if his canter be false or true, and she should acquire the means, of making him rectify his action.

A horse must not be allowed to canter with either leg leading at his own will, but must be 
made to do so, at the will of the rider. When cantering with the off fore-leg leading, the pace is more agreeable to the lady, consequently a lady's horse should be taught to start off into a canter, with his right leg leading. There are many opinions, as to what are the proper indications to be given to the horse, to induce him to lead with either particular leg, but considering that a horse when cantering in a circle to the right, must lead with the off-fore, and that the indications in that case are, a double bearing upon the right rein, and an increased pressure with the leg, or whip on the left side of the horse, these appear to be the most rational.

To start the horse into a canter with the right or off-fore leg leading. The lady having her horse properly animated, light in hand, and well balanced, should, as in the walk, draw the horse's attention, by an increased bearing upon both reins, but upon the right rein the stronger; and at the same time, by a strong pressure of the leg, or heel, and by the applicacation of the whip to the horse's left shoulder, communicate to him, an impulse to carry him forward. If the horse hesitates to canter, she should pass the whip behind her waist, and strike the horse on his near-hind-quarter; the whip must not be used on the right side of the horse, because muscular action being retractile, 
doing so, would cause him to draw back his right leg, rather than to advance it before the left.

To start the horse into a canter, with the left leg leading, the extra bearing must be made upon the left rein, and the horse should be touched with the whip on the right shoulder or flank. It is an excellent lesson to cause the horse to change the leading leg, when in the canter, so that upon any disturbance of pace, or change of direction, the action of the one, may be as familiar, and as easy to the rider, as the other. The lady should sit well down in the centre of the saddle, with her body perpectly upright, and square to the front, without stiffness or constraint, she must continue the bearings upon the horse's mouth, throughout the entire pace, and if the horse flags in his movements, or does not respond to the action of the bridle-hand, then the whip must be instantly applied. In turning a corner, or cantering in a curve, the lady must incline her body in that direction, to preserve her balance, and she must be careful that the bridle arm, does not acquire the bad habit, of moving from the side of the body, and throwing the elbow outwards.

The gallop, is a further increase of pace upon the full canter, but no lady of taste ever gallops on the road, into this pace, the lady's horse is never urged, nor permitted to break, excepting in 
the field. The action being the same as that of the canter, excepting being more extended and quicker, nothing further need be said in this place.

\section{LEAPING.}

A lady's horse must be perfectly steady, and thoroughly trained, before she attempts to put him to a leap, Leaping is beneficial, as it tends to confirm the seat, and enables the rider more effectually to preserve her balance, should she ever be mounted upon an unsteady, or vicious horse.

The skill in leaping consists principally, in the rider's own accute anticipation of the horses spring, and in participating in his movements, going over with him, as a part of the horse's-self; she must not, by being late, and hanging back, have to be jerked forward by the spring; which operating at an angle of the person, pitches the rider over the horse's head, before the animal's fore-quarters reach the ground.

Preparatory to the leap, the rider should take up the snaffle rein, and slacken the curb; because the snaffle acting in the corners of the horse's mouth, lifts up his head, and allows him more freedom, whereas the curb-bit acting lower down in the mouth, tends to draw the head and chin inwards, towards the breast, and restrains his power of extension. 
Leaps are of two kinds, the "standing". and the "flying." -In the standing leap, or leap over a height from a standing position; the horse raises himself on his hind feet, and springs from his hind legs, throwing himself over the object. The flying leap, is taken from any pace, it differs from the standing leap, principally in agility, and in the horse being more extended in his movements.

The position of the rider is to be governed in this, as in all other cases, by the action of the horse; no weight should be borne on the stirrup, the right leg must press strongly the middle pommel, and the left, be closed to the saddle. The bridle should be held so as to offer no check to the horse's movement, but should the horse show an unwillingness to jump, or be inclined to swerve, it is prudent to keep him firmly in hand, until the moment of his spring, when the tension on the reins may be lessened.

$A$ standing jump.-The rider must press her leg close against the saddle, she must animate the horse to jump, by gently lifting his head; as he raises on his haunches for the leap, she should yield the reins, to give him ample room to extend his neck and shoulders, and to exert himself; as his fore-quarters ascend, the lady should lean slightly forward, keeping her head upright and steady ; as he springs, she resumes her upright position, and 
as he descends, she inclines her body backwards to balance herself; urging, and at the same time restraining the horse, to induce him to collect, and fully recover himself upon his legs.

The flying leap.-In the flying leap, the seat is to be preserved, as in the standing leap, but the horse's posture being more borizontal, the lady need not lean forward as he raises; she must approach the leap in such a manner, as neither to hurry or flurry the horse, but so as to allow him a full view of the place he has to go over. Holding the horse's head with the snaffle, with a firm but delicate hand, straight to his jump, she brings him up at an animated pace. As he springs, she must slightly yield the reins, as he descends, she must incline her body backwards pressing her left leg firmly to the third crutch, and looking straight to her front, she will retain her seat and balance immoveably; she then resumes the tension of the reins; and the moment the horse touches the ground, she should be prepared to use her whip if necessary, to induce the horse to collect himself, to prevent him from stumbling or falling.

\section{ROAD RIDING.}

WHEN persons are pursuing their business or pleasure on the road, precise formality, and at- 
tention to the strict rules of riding, would interrupt their enjoyment.

The rudiments of the art being once known, when on the road, no more of it is to be applied, than will, with the greatest ease, facilitate our designs. When nothing more is required of the horse, than to perform the natural paces, he will walk, trot, and gallop with the greatest freedom. The rider participates in the like ease, or unrestrained liberty, but this ease or inattention, is not to suffer unseemly habits to take place, such as the back and shoulders to get round, the head to shake, the leg to dangle, and beat against the horse's side.

These errors may creep on a person, who has not been confirmed in the principles by sufficient practice; but when habits of good riding are once firmly established, the ease and liberty the rider assumes, will not exceed propriety, risk her security, nor abandon, nor baffle her horse,-her hand will keep its situation and properties, though the body be turned to any extreme for the purpose of conversing, and the like, nor will the body by any freedom it takes, throw itself out of balance, nor take the liberty, when it cannot be done with safety. This freedom and ease, so desirable and so universally admired, is affected by every person who is in the habit of riding, but with this difference, some 
possess system, with negligence, and ease, and others merely negligence and ease, without system.

A lady's horse should be sure footed, but the best become careless. When a horse trips, he should be kept more than usually collected. It is useless to whip a horse after stumbling, as it is also after shying, for it is clear, he would not run the risk of breaking his knees nor his nose if he could help it. A bad horsewoman throws her horse down, which a good horsewoman does not do. That is, because a bad horsewoman hurries her horse, orer bad ground, or down hill, or over loose stones, or rough and broken ground, lets him flounder into difficulties, and when there, pulls him so that he cannot see, nor exert himself to get out of them, and expecting chastisements, the horse springs to avoid it, before he has recovered his feet, and goes down with a tremendous impetus; if she have to cross a rut to the right, she probably forces her horse across it, when the right foot is on the ground; in which case, unless the horse collect himself, and jump; if he attempts to step across it, the probability is, that crossing his legs, he knocks one against the other and falls. The reverse of all this, Colonel Greeswoon, writes, should be the case, if the lady have not sufficient tact to feel, which of her horse's feet is on the ground, she must allow him his own time for 
crossing, which will be, when the left foot is on the ground. The rider should habitually choose her horse's ground for him, this by practice, will be. come as easy to her, as choosing her own path when walking.

It is a common error to suppose, that a rider can support a horse when falling, lift bim over a leap, or hold him up, they are mechanical impossibilities. Were a similar weight attached to the thin rein of a lady's bridle, could the lady lift it with her left hand. A pull from the curb, will indeed give the horse so much pain in the mouth, that he will throw up his head, and the rider flatters herself that she has saved her horse from falling ; but this error is not harmless, by so doing, she prevents his seeing to foot out any unsafe ground; and further, when an unmounted horse stumbles, nature teaches him to drop his head and neck, which relieves the shoulders of their weight, and that is the instant that the horse makes his effort to recover himself; the muscular power employed to raise the head and neck, will act to sink his knees, for as much as the rider pulls up, so much will she pull down. The great point is, to keep the horse so well balanced and in hand, with his legs well under him, that should the horse stumble, or get into difficulties, he is able to recover himself without much exertion. 
When proceeding along a road, the rule is, to keep to the left side of it, but when about to pass those travelling in the same direction, though at a less speedy pace; to pass on their right. A party meeting another passes to the right, that is, the right hands of the parties meeting, are towards each other.

$A$ gentleman riding with a lady, should be on her right side, as on that side, if the road be dirty, he does not bespatter the lady's habit, and on that side also, he is situated next the carriages, and various objects they meet, or which may be passing near them.

If a lady find her horse become affected and uneasy in his gait, she should endeavor to ascertain the cause, the probability is, there will be found to be something wrong, in the bridle or saddle or perhaps a stone in the horse's foot, and she should have it remedied if possible.

A lady should also habitually prevent her horse out-walking, or lagging behind her companions, she is either very unsociable, or a bad horsewoman, who does not keep abreast of them.

A lady, although advised to ride in general on the curb bridle, should occasionally use both hands to the reins. It assists in obtaining a firm seat, by giving greater power and command over the horse; it prevents the strain on the left arm, 
which is the natural result of holding a horse entirely with one hand, it makes the pressure upon the animal's mouth more even, which is so truly essential to the comfort of both horse and rider, it keeps the shoulders square, a very important point in the elegance of a young lady's appearance, it causes the elbows to be even on either side instead of one being infinitely in the rear of the other, as is too often the case, and though last not least, it keeps the whip quiet until its use is called for.

There is a piece of inhumanity practised, as much, perhaps more by ladies than by gentlemen, it is, rilling a horse fast on hard ground. If the ground be hard and even, a collected canter may be allowed, but one hour's gallop on hard and uneven ground, would do the soundest horse irremediable injury, his sinews would be strained, his joints prematurely stiffened, fever in the feet would be produced, and the horse would be deprived at once, and for ever, of his elasticity and action, and be brought prematurely a cripple to the grave.

DISMOUNTING.

THE first operation preparatory to dismounting is, to bring the horse to an easy yet perfect stop. 
If the lady be light, and dexterous, she may dismount without assistance.

The lady when preparing to dismount, should take the reins in her right hand, and put the whip in her left. The reins should be held sufficiently tight, to restrain the horse from advancing; and yet not so firmly, as to cause him to back, rear, or swerve.

The lady should next disengage her right leg from the pommel clearing her dress as she raises her knee; place her right hand on the near crutch, and take her foot out of the stirrup.

If the lady be assisted, the gentleman taking her left hand in his left, places his right hand under her left elbow, which she keeps firm to her side; as she springs, he supports her in her descent, she retains hold of the crutch or of the hunting pommel; as she quits the saddle, she turns to face the gentleman, who stands near the horse's shoulder, and alights on the ground on the balls of her feet.

If the lady dismount without assistance, after clearing her foot from the stirrup, she places her right hand on the near crutch, and her left upon the third crutch or hunting pommel, she must spring clear from the saddle facing towards the horse's side as she descends. By whatever mode the lady dismount, she should, to prevent an un- 
pleasant shock on reaching the ground bend her knees, suffer her body to be perfectly pliant, and alight upon the balls of her feet; she is not to relinquish her hold, nor the gentleman to withdraw his support, until she be perfectly safe on the ground.

\section{CONCLUDING REMARKS.}

RIDING for recreation, and riding for improvement, are distinct things, yet both are necessary. Many persons unacquainted with the principles of "Horsemanship," can perceive no other excellence, than riding boldly, and riding fast, and some even assert, that a Lorse broken by a riding master, has been spoiled; this idea is easily accounted for, as the better a horse is broken or educated, the more unsuited he is for an awkward rider.

There are many, it is true, who have been in the habit of riding from their infancy, who, although they never have had any instructions, ride hunting, or on a straight road admirably well; but many more affect to ride as well, who commit the greatest absurdities.

Though the ordinary modes of riding may gratify, and convey one on a horse's back, wherever the will directs, yet, from want of knowledge of the true principles of riding, one is continually exposed to innumerable hazards. 
Most persons are desirous to ride well, though not in a manége style. To ride well, a lady must be perfectly at her ease, with a hand capable of managing her horse, with facility to herself, and comfort to her animal. These requirements will be sooner attained, by a few proper lessons, with study and application, than by years of riding without them.

To conclude, a lady on horseback cannot look too quiet; she should appear perfectly at her ease, and in perfect temper with her horse; in short whether natural, or acquired, she should seem, " born with a sweet temper, a light hand, and a good seat." 


Webster Family Library of Veterinary Medicine Cummings School of Veterinary Medicine at Tufts University

200 Westboro Road

North Grafton, MA 01536 

. 